\title{
The Investigation of Educational Reform for Economic Mathematics Combined with Financial Characters
}

\author{
Lingling Dong \\ Financial College \\ Qilu University of Technology, \\ Jinan, Shandong 250100, China \\ D00zdy@163.com
}

\begin{abstract}
Highly skilled talents with deep theoretical foundation and ability to apply mathematical method to financial analysis are needed in the "new normal" phase of the economy. Under the orientation of "training applied talents for local economy", aims at the current situation of students' foundation, the author investigates the educational reform for economic mathematics combined with financial characteristic, points out that the goal of teaching reform is to cultivate students ' ability to apply mathematics, and puts forward a concrete scheme to explore the blended teaching mode. The author adopts many methods to stimulate students' strong interest in economic mathematics, thus improves the teaching effect.
\end{abstract}

Keywords-blended teaching; reform of teaching; economic mathematics

\section{INTRODUCTION}

Mathematics is widely used in many fields. Almost all the big events in human history were supported by mathematics, such as the Copernicus' heliocentric theorem, Newton's law of gravity, the opening of the DNA double helix, cloud computing and big data and so on. And with the development of science and technology, mathematics is becoming more and more permeable to other areas.

China's economic has entered the "new normal" stage since the 18th National Congress. A deep change is taking place in the environment of educational system, especially in the environment of higher financial education. In the current financial situation, we are required to cultivate combined of financial talents with solid financial skills, conform to the rules of financial markets and dabble in many financial field. Mathematics provides strong tool base and basis for decisionmaking, and it plays an increasingly important role in the development of economics.

Under the orientation of "training applied talents for local economy" in our college, and with the name of improving students' understanding and application of mathematics, we have carried on a further exploration and comprehensive practice to the reformation of economic mathematics teaching system.

\section{The Necessity of Teaching Reform with FinanCial CHARACTERS}

Economic mathematics, which is one of the basic courses for students in finance and economics, plays an important role in improving the quality of students. But the monotonous teaching content and the old boring examples can't either arouse students' interest in learning or improve students' quality. It is extremely urgent to update the teaching content of economic mathematics as the request of times.

The implementation of the nation action plan "Internet +" makes education informationization the only way to accelerate the modernization of education. The better resource and more open environment provide support and assurance for the healthy and rapid development for modern education. The traditional teaching methods have limited knowledge capacity, and the teacher is in the absolute dominant position in mathematics teaching. On the other hand, some teachers use the new multimedia teaching, but just play the content on the teaching courseware, and the teaching effect no doubt is very poor. So the innovation of teaching method becomes an important part in our teaching reform and experience.

For the above reasons, we devote ourselves to update the teaching content of economic mathematics and seek teaching method which fits the economic mathematics' teaching system rely on information technologies.

\section{The Course Features of Economic Mathematics UNDER THE ORIENTATION OF "TRAINING APPLIED TALENTS FOR LOCAL ECONOMY”}

Education works on students. Students are the staring and the end point of education. And the students, as the subject of education must have subjectivity, which is embodied in the active posture and dominant position of the subject in the process of objectiveness. That is, as the subject of study, students must have conscious dynamic role. So the process of mathematics education is not only the way through which teacher to organize the implements of education activity process according to certain regulations but also the process of self-development by college students through their own internal needs and activities. 
As the whole world is concerned about the students' application ability in mathematics today, 'Mathematical Problem Solving Instruction" is put in an important in national program standards. Mathematics is an abstract logical thinking process in essence[2]. Under the orientation of "training applied talents for local economy", our reform train of thought is to train students' ability to apply mathematics focusing on student major. We are committed to a comprehensive application of new media for blended teaching around students' major. Through the learning of economic mathematics, we hope the students can use mathematics as a basic tool to think and to interpret economic problems.

So the course features of economic mathematics in our college are: From an economic perspective, according to system of mathematics, and insist on both the accuracy of mathematics and the application of economy, integrate the professional knowledge into economic mathematics teaching.

\section{The Practice Exploration of Economic \\ Mathematical Teaching Reform Under Financial CHARACTERS}

We carried out the practice and exploration of economic mathematics teaching reform under financial characteristics combined with years of teaching experience. Specifically, our reform consists the following aspects.

\section{A. Set the Teaching Goal and Revise the Syllabus Combined with the Financial Characters}

In the current background of economic globalization, the development of local financial requires us to cultivate the skilled talents with profound theoretical foundation and broad international vision and master the mathematical methods for financial analysis. And this requires students not only to master mathematics practice theory and statistical calculation method but also to train their rigorous thinking through the mathematical characteristic of the rigorous logic[1].

In the process of economic mathematics teaching reform, we always adhere to the principle of pedagogy, the combination of teaching theory and concrete practice, and the combination of classical mathematics theory and discipline construction requirements. So we set the goal of economic mathematics teaching: to cultivate students' ability to master mathematical knowledge and solve economic problems by mathematical methods.

\section{B. Update Teaching Content Keeping with Modern Times}

The knowledge of higher mathematics is infinite just like a vast ocean. But, as one of the basic courses for students in finance and economics, economic mathematics does not need so much knowledge quantity, nor too deep. So we take the initiative to study specialized courses and communicate with professional teachers, know the training objectives of each major and mathematics knowledge that is required in specialized courses. And on this basis we update the contents of economic mathematics in line with practical and sufficient principle,focus on the combination of serious mathematical knowledge with vivid economic examples.

Under the premise of maintaining the systematic content of mathematics, we sorted out the contents of our textbook: pay less attention to theory, lie upon practicability, and optimize examples. Some examples: drawing and examples in our daily life can be employed in the teaching of Limit to help students to understand concepts easily and relatedly, no more emphasis on the " $\varepsilon$-language", introduce abstract theorems with examples.

\section{Apply Blended Teaching With the Financial Characters of Our College Relying on the Information Technology}

With the development of information technology, more and more researchers are attracted by MOOCs and flipped class with their high flexibility and extensive participation in recent years. Many universities or colleges can’t carry out MOOCs because of the lack of resource. But they can apply the online teaching materials to teaching relying on the information technology[3].

On the basis of inheriting and criticizing the teaching thought of blended teaching theory and the reform of classical teaching, and throughout the practice of teaching, we form a blended teaching method of three links: self-regulated preparation(guided learning plan, micro-course online video, MOOCs), classroom teaching interaction (discussion between teacher and student, question exploration), consolidation after class (online homework, problem solution), with which we obtain quite good teaching effect. Let's elaborate on that. First, teachers compile guided learning plan combining the discipline construction and teaching purpose of the college, and students prepare lessons with the help of guided learning plan and the learning materials online. Second, teachers give a comprehensive lecture on the contents and organize the discussion about it, guide students analyze and explore induction, and evaluate. Finally, teachers help them to consolidate knowledge in the form of homework and answer the students' questions in all kinds of ways.

Our blended teaching method is not a simple accumulation for all kinds of teaching means. It is a new teaching method combined of advantage of both traditional teaching and digital teaching. This method can't only play the leading role of teachers, but also reflect the students' dominant position. Students' study of the basic knowledge points before class reduces the times for teachers to teach knowledge in class and increase the time for interaction and discussion between teachers and students[4]. Take the study of partial derivatives of multiple functions for example. Students have mastered the concept and operation rules of single variable functions before. After the students' preview according to all the material, the teacher guides students to inspires their lateral and longitudinal thinking by review, to discover the concept and operation rules about functions of several variables. Finally, guides students to compare the two types of functions, and summarize[5][6]. The knowledge gained this way will leave a deep impression on the students' mind and students will remember them more firmly, use them more freely.

Practice shows that our blended teaching method with financial characters can help to enhance the activity of students in their study, to inspire their passion to learn, and to cultivate their creativity and consciousness of scientific research. 


\section{Learn to Meet Practical Needs: Carryout Practical Courses Such as Mathematical Modeling}

Mathematics is very important. But we must admit that it is boring for many students. The idea of mathematical modeling is: analyze the real problems in our daily life, turn them into the relationships or laws that can be described in mathematical language, and then solve the problems. This sense of authenticity and usefulness will greatly stimulate students' interest in learning mathematics[7].

Problem is the heart of mathematics. Students can deepen their understanding of mathematics knowledge and strengthen their mathematics thinking in solving problems. It is an effective way for cultivate students' ability of mathematical application, practice and innovation to carry out mathematical modeling. And we also introduce Matlab, Lingo and other mathematics' application into class. Let the students learn to use the computer to carry on the mathematics study, stimulate their learning enthusiasm and cultivate the students' self-study ability.

Mathematical modeling and other types of mathematics' application make a foundation for students' lifelong learning, while cultivating their spirit of solidarity, and laying a good foundation for the future work.

\section{E. Explore the Comprehensive Mechanism of $N+1$}

Teaching evaluation is a key link of teaching activities, which can diagnose the teaching efficiency, monitor the teaching activities and better the students' learning. The original mathematics examination method of our college was evaluated by the final examination. This kind of assessment method cannot do justice to the students' learning effect. The comprehensive mechanism of $\mathrm{N}+1$ includes all the performance of each link in teaching, such as the ability to question and the comprehensive practice ability. In which $\mathrm{N}$ refers to the evaluation of the students' thinking quality, attendance and homework, formative assessment and so on. 1 refers the financial examination.

Different evaluation methods are adopted for different levels of content in this comprehensive mechanism. For example, we use formative evaluation for the knowledge of level mastery. And we should combine primly the qualitative evaluation and the quantitative evaluation when we make the final evaluation.

Facts have proved that this way of examination can help students set up the correct learning attitude and cultivate their self-study ability. We will also compare and judge the evaluation system constantly in the teaching, and from which we better our teaching.

\section{CONCLUSION}

The topic of educational reform is without endless. Some achievements have been made in our investigation of educational reform for economic mathematics combined with financial characters; however, there is much to be improved. The blended teaching method makes higher demands on teachers. We will continue to study deeply and explore the highly effective teaching method. Only in this way can we train more and more skilled personnel, who have both ability and integrity with high quality, for our country's modernization.

\section{REFERENCES}

[1] J.H. Ren, “Cultivate Financial Experts Comply with Financial Reform”, China Higher Education, 2016,(9), pp. 53-54.

[2] W. Sun, "Construct the Higher Mathematical Teaching System in Financial Applied Undergraduate University by the Leading of Specialty”, Journal of Harbin Finance University, 2012,(3), pp. 79-80.

[3] L.L. Dong, "Research on the Shock to China's Traditional Higher Education Brought by MOOCs and Corresponding Tactics”, China Adult Education, 2013,(23), pp. 145-146.

[4] Q.L. Zhang, A.C. Wang, “The Investigation on blended teaching form based on flipped classroom”, Modern Education Technology, 2014.(4), pp. 27-32.

[5] J.S. Drysdale, C.Graham, K.J. Spring, et al. "An analysis of research trends in dissertations and theses studying blended learning”, The Internet and Higher Education, 2013,(17), pp. 90-100.

[6] W.W. Porter, C.R. Graham, K.A. Spring, et al. "Blended learning in higher education: Institutional adoption and Implementation”, Computer \& Education, 2014,(75), pp. 185-195.

[7] D.M. Yao, "Research on the influence of mathematical modeling contest on the reform of higher mathematics teaching", Contemporary Educational Science, 2014, (11), pp. 60-61. 